\title{
Balkanologie
}

Balkanologie Revue d'études pluridisciplinaires

Vol. V, no 1-2 | 2001

Volume V Numéro 1-2

\section{Homelands in question : Paradoxes of memory and exil in South-Eastern Europe :Introduction au dossier}

Keith S. Brown

\section{CpenEdition}

Journals

Édition électronique

URL : http://journals.openedition.org/balkanologie/703

DOI : 10.4000/balkanologie.703

ISSN : 1965-0582

Éditeur

Association française d'études sur les Balkans (Afebalk)

Édition imprimée

Date de publication : 31 décembre 2001

ISSN : 1279-7952

Référence électronique

Keith S. Brown, « Homelands in question : Paradoxes of memory and exil in South-Eastern Europe :Introduction au dossier », Balkanologie [En ligne], Vol. V, n 1-2 | 2001, mis en ligne le 02 juin 2008 , consulté le 17 décembre 2020. URL : http://journals.openedition.org/balkanologie/703 ; DOI : https:// doi.org/10.4000/balkanologie.703

Ce document a été généré automatiquement le 17 décembre 2020.

(c) Tous droits réservés 


\title{
Homelands in question : Paradoxes of memory and exil in South- Eastern Europe :Introduction au dossier $^{1}$
}

\author{
Keith S. Brown
}

1 It is well-known that nationalism simultaneously invokes ideas of blood, home and rootedness, to create for citizens and outsiders the impression that village, town, region and nation represent a "nested" set of loyalties. But where people are driven out, or where refugees or exiles from elsewhere are incorporated into a nation-state, the distance between the metaphorical and literal meanings of these central terms is stretched. Official discourses are often silent on this score : it is in the experiences of displaced people, and in their narratives of the past, that the strains are most apparent. It is also at this level that we can trace how human agents recreate meaning and order from their fractured lives, formulating alternative views from those of the states they have left or entered. The papers collected here draw on histories of displacement in South-Eastern Europe to explore paths of analysis which may serve as the startingpoint for a critique of the nationalist vision. Moving beyond familiar arguments of the "invention" or "imagination" of national belonging, they provide the basis for new ways of thinking about emergent and resistant solidarities.

\section{Historical contexts}

2 Histories of South-Eastern Europe often focus on the deep, historical roots of its communities. The idea of continuous residence on the same soil, from time almost immemorial, has a powerful grip on the imagination of various constituencies in the present. Insistence on autochthony is a characteristic of nationalist thought, for example, and frequently combines with an enthusiasm for ancestral markers of advanced civilization. But scholarship too has made its contribution to an emphasis on 
the static and enduring dimensions of human lives in the region : so too have foreign partisans or sponsors of one group or another. The interplay of different agents in shaping perspectives on the past is especially clear in the case of nineteenth-century Greece, which was carved out of the Ottoman Empire. Whether construed as a bulwark of Europe, repository of classical Hellenic values, or heir to the Byzantine legacy, it was transformed from Turkish province to Greek homeland through a combination of material and symbolic work by its sponsors and newly-defined members ${ }^{2}$.

3 Yet alongside a history of sturdy farmers who keep their places, and great arcs of national continuity, runs another narrative thread, in which human relocation is recurrent and defining. Interviewing Macedonian villagers in the 1930s, the Polish ethnographer Josif Obrebski discovered that they preserved tales of their founding ancestors' arrival from elsewhere in the site of their current residence ${ }^{3}$. In her work in Greek Macedonia, Lina Sistani records somewhat similar preserved origin myths ${ }^{4}$. In mountain villages all across the region, in particular, as well as on some of the Aegean islands, one can encounter tales of former settlements abandoned, especially for reasons of security, and communities relocating to better hidden, more defensible locations ${ }^{5}$. In all these cases, then, the current and undoubtedly cherished "home" turns out to be ancestral only up to a point. Prosperity and pride in place are built upon the ruins of former lives, often lived elsewhere.

4 At this most intimate level, such relocations appear of little significance in the present. The same cannot always be said of larger-scale displacements, especially those that occurred in the twentieth-century, and with which the papers in this collection are concerned. Three elements in particular distinguish the such movements from those conducted at the village level. In the first case, relocation was generally forced upon them not by fear of predatory pirates or bandits, but by pressures brought about by conflicts between states or between ideological opponents within a state. They did not merely decide to relocate to remove themselves from potential harm: they found themselves in situations where they were perceived as potential enemies or traitors to the state in which they lived. Secondly, as a direct consequence of this, they were pressurized not simply to move, but to move across a national boundary. The journeys they took were often long in literal terms, but their sense of distance from their former homes was further increased by the power of the frontier, which added bureaucratic obstacles to any return. Thirdly, the territory into which they moved was already perceived as home by an existing population. Although these movements were often represented at the state-level as repatriation, it is clear that the new settlers and their new hosts or neighbors did not generally see things in such straightforward terms. sharing the same space, and in some cases competing for scarce resources, they were often acutely aware of cultural, social and linguistic differences.

\section{Memory and Exile : anthropological approaches}

5 The papers in this collection are for the most part by anthropologists, and draw upon a tradition of study of groups displaced by wars over national belonging. Peter Loizos' harrowing account of Greek Cypriot refugees, for example, provides a key resource for much subsequent work ${ }^{6}$. In a new foreword to Renee Hirschon's 1989 study of an urban community of refugees from Asia Minor in Athens, Michael Herzfeld suggested that it offered important comparative insights in the wake of late twentieth-century crises in 
Rwanda and Bosnia ${ }^{7}$. As Herzfeld indicates, Hirschon's particular concern with space and place foreshadowed developments in the discipline, which led to a number of volumes that explored the presumptive "rootedness" of culture and introduced discussions of mobility through the alternative imagery of "routes".

The significance of collective or individual memory in the maintenance of identity, and especially the role of narratives of loss and nostalgia, has also been investigated. Jewish experiences have constituted one focus for such work, but anthropologists have also extensively documented the importance of oral and written accounts of the past for others caught up in state violence, notably Palestinians and Sri Lanka's Tamils9.

One of the most influential recent anthropological works on refugees is Liisa Malkki's study of Rwandan refugee communities in Tanzania ${ }^{10}$. There, she elaborates the important observation, that different experiences of exile may lead to different ideas about identity, and especially to the formation of distinct modes of historical consciousness. In the Tanzanian context, she argues, there was a significant divergence between the degrees of attention paid to and significance attached to the past. While refugees in camps, sequestered from the local population, appeared to cling onto the legacy of the homeland, and embraced the category of refugee as indexing their dreams of return, those who had made their lives in larger cities were more committed to leaving their experiences behind, and making a new life. To do so, they often actively resisted categorization as refugees, seeing it as a first step in their being returned to the camps or to the country they had fled. Instead, they sought means by which they could assure their residency status in the towns, and paid particular attention to the acquisition of identification documents which categorized them as non-refugees.

Similar concerns inform works on the Palestinian case, where George Bisharat and Julie Peteet have traced independently distinctions in identity politics between long-term camp residents and those who reside in towns or cities ${ }^{11}$. In this case, a longer time has elapsed since the original displacement, which leads both to refine Malkki's categorical distinctions. Both indicate the persistence of stereotypical ideas linking individual characteristics to specific places of origin, while also highlighting shared dimensions of subsequent experience which generate narratives that are, in Peteet's words, " consistent.... though certainly not interchangeable $»^{12}$. She suggests that the term "refugee" was for an extended period rejected by Palestinians in Lebanon, who preferred the term "returners". Only after 1982, she argues, did they embrace the term "refugee" as a strategic necessity, in order to bargain with international agencies and governments for recognition of their rights ${ }^{13}$.

9 Writing of the West Bank, Bisharat charts a similar transformation, arguing that « refugee status (...) has been, alternately, a brand of disrepute, a strategy for survival, a badge of entitlement, and a moral claim ${ }^{14}$. While "return" remains a powerful uniting ideology, it no longer indexes commitment to a physical homecoming-most homes have been destroyed-but refers instead to a " "Palestine" conceived abstractly", standing for an ideal future existence free of Israeli rule ${ }^{15}$.

In her forthcoming study of Italian exiles from Yugoslav Istria, Pamela Ballinger suggests that this transformation may not always be clearly marked. She argues that members of this community nourish multiple dreams of return, all of which she describes as forms of redemption, in the following terms :

Previous winners and present losers, the Istrian Italians hope for eventual redemption: redemption at the symbolic level (the recognition of the esuli's 
"forgotten history"), in memory (Istria living again in the hearts of these survivors), and in pragmatic terms (actual return of properties in Istria. Demands for legal and historical justice rest upon the moral quality of exile accounts qua biblical epics, which tell a tale about the betrayal and sacrifice of Istria's Italians, innocent victims who paid the price for fascist Italy's sins just as Christ paid for those of mankind ${ }^{16}$.

11 As Ballinger suggests, members of long-term exile communities often appear to slide easily between emphasizing individual innocence and expressing collective entitlement. In this regard their rhetorics reinforce those whereby new immigrants have historically been constructed as the equivalent, in a national sense, of newborn infants ${ }^{17}$. Political activism prior to the moment of displacement is by this formulation either forgotten or denied, as the community is retrospectively classified as living quietly on territory that was unquestionably theirs by right. Those driven from their homes are neither willing nor witting agents, and in this regard they can be conceptualized as children, vulnerable to larger historical processes, or the particular animus of some alien aggressor. Such narratives of belonging and attachment thus present the inhabitants of the past as bearing no blame for what befell them: their individual circumstances are sharply distinguished from those whose actions may have prompted their expulsion. By contrast, flight is often perceived as a moment which burns into people's consciousness, and makes them aware of the necessity for collective action to restore their former fortunes. Will, it seems, is born in motion.

What these various accounts indicate is the recurrence of both narrative motifs and sociological dimensions in different refugee movements. From Cyprus, Palestine and Istria, anthropologists have recorded people cherishing the key to their old house as a talisman that betokens faith in return ${ }^{18}$. Spatial concentration, either in a camp or a specific quarter of a town or city, seems also to encourage the preservation of social memory, through the reuse of familiar place-names, and continuing patterns of sociability and intermarriage ${ }^{19}$. What also emerges, though, is the diversity of experience, even within small communities. In Cyprus, for example, Loizos notes that the hardest hit by displacement were those who had invested most in the village, such as farmers, or married couples, especially women, who had worked and saved for years to build a house which was now lost. Young unmarried men, and those men whose livelihood had oriented them towards a wider world of business, adjusted more quickly ${ }^{20}$. Ballinger likewise emphasizes the importance of gender and age in shaping reactions to their exile: young people in particular reported a sense that greater opportunities opened for them ${ }^{21}$.

\section{The papers}

13 The papers in this collection explore different cases of forced migration in twentiethcentury South-East Europe, and draw on a variety of analytical and narrative methods to do so. Nergis Canefe's paper is the most historical and theoretical and the least ethnographic, and provides an introduction to the core issue of how the nation-state handles its "impurities"-legacies of cultural diversity within the frontiers which, ideally, enclose a homogeneous people. Focusing specifically on the case of Asia Minor and its displaced Greek population, Canefe takes a hard look at the politics of the production and commodification of new, nostalgic histories of the Ottoman legacy, and 
cautions that revisionism can serve simply to replicate nationalist moralities of "good" and "evil".

Miladina Monova's paper demonstrates how even in a highly politicized case, the resettlement of Aegean Macedonian, or Egejci, in the Republic of Macedonia after the Greek Civil War, oral historical material and social anthropological methodology can yield insight, rather than enflame polarized debate. Employing a deliberately anecdotal, journalistic style in recounting his journey to document the experiences of the Muslims of Bulgaria who were "encouraged" to leave for Turkey after 1989, Petar Krasztev similarly shows the complex and shifting nature of solidarity and cultural memory. Both these accounts focus on the lives and choices of economically active groups who found themselves living in close proximity to people who were supposedly "the same", but from whom they saw clear differences. These are both cases in which residential segregation, partly chosen, partly imposed, affects community solidarity : in both cases, too, the roles that women play in the workforce serve as a point of distinction. In the context of socialist-era Macedonia, the displaced Aegeans in Prilep were quicker to abandon prejudices against women working outside the home than their native neighbors. Thus although land-poor, families more quickly acquired capital: and although initially disdained for such practices, over time gained greater status. Krasztev's work, conducted only seven years after the displacement and at a time when rumors still circulated that the "Bulgarians" might again find themselves relocated as a result of international intrigue, demonstrates how migrants from the Bulgarian socialist system likewise proved adept at utilizing labor resources, and quickly took pride in an adaptive individualism that distinguished them from their new neighbors.

15 The papers by James, Akgonul, Tsimouris and Tanc address different aspects of the population exchanges of the 1920s, during and after the Greek-Turkish war. Taken together, they offer a multi-sited response to Canefe's call for many-sided history. Alice James discusses the settlement of Asia Minor refugees on Chios, the closest and largest island to the coast. Confirming many of the findings of Renee Hirschon's work in the Piraeus, James stresses the role of icons, photographs, and other material remnants of former lives in the cultivation of memories of loss. James' account suggests that this process is a product of ongoing social interaction among former refugees, who still share particular neighborhoods and engage on common commemorative projects.

Akgonul, by contrast, considers the relative lack of refugee solidarity among Muslim refugees, or muhacirs, who were compelled to leave Crete and Macedonia for Asia Minor in the 1920s. Offering a range of oral historical interview material, the paper highlights the difficulties that the muhacirs faced in their new environment. Tensions with their new neighbors are much more a part of Akgonul's account than James', prompting secondary displacement as many families abandoned the rural locations where they had been settled to move to cities. As was the case with the immigrants from Bulgaria after 1989, they were often settled in areas with large Kurdish populations, a phenomenon that contributed further to the ambiguity surrounding the relocation: was it repatriation, or colonization of marginal territories ${ }^{22}$ ? Even when situated among Turks, they perceived themselves, and were perceived, as alien, as is demonstrated by the remark that Akgonul cites from a resident of Honuz, who reportedly said «the Greeks have left, other Greeks have arrived. Where is the difference?» Such slippage in identity-ascription, argues Akgonul, characterizes 
muhacir history : young descendants of the refugees still might identify themselves as Macedonian or Cretan, but no longer does this compromise their senses of Turkish citizenship or nationality.

The papers by Tsimouris and Tanc carry the analysis one stage further, as they contemplate cases where links across the borders of national identity remain vital. Where the separation of lost homeland and new residence is clear-cut for those refugees from mainland Asia Minor, it is much less so for the Orthodox islanders of Imvros, who were exempted from the population exchange of the 1920s. Tsimouris documents how international pressures, especially over Cyprus in the 1960s and 1970s, impacted life on the island, with the result that many families elected to leave. In contrast to the mass exodus of the 1920s, though, their resettlement in Greece was not assisted by international organizations : nor was it welcomed by the Greek state, for which the continuing presence of this Greek Orthodox community in Turkey had enduring symbolic significance. Many exiled Imvriotes thus felt multiply betrayed by Greece, first for not doing more to protect them from Turkish intimidation or victimization, and second for making it difficult for them to obtain Greek citizenship. Yet as Tsimouris describes, they also have a troubled relationship with those members of their community who elected to remain on Imvros, and who give the impression of being more concerned to maintain relations with their Turkish neighbors than celebrate their Greek identity. At yearly festivals held on the island, and now attended by many exiled Imvriotes, tensions over property ownership, inheritance and the constraints posed by national citizenship all surface in the conversations and commentaries of residents and visitors recorded and analyzed in Tsimouris's paper.

In the final paper of the section Barbaros Tanc, working through the medium of oral autobiographies, traces the way in which diverse lives are linked to the Anatolian village of Kayakoyu, formerly known as Livissi. Tanc juxtaposes three perspectives : he interviewed refugees who were forced to leave the village, those from elsewhere that were compelled to settle there, and residents whose families stayed in place. In each case, the lines between national and local belonging are drawn slightly differently. Many of the themes explored in other papers are here inter-related, as Tanc describes how refugees from villages close to cosmopolitan Salonika encountered culture shock in this new rural location, how returning after long absence reawakened past sensations for a Greek leftist, and how long-term residents saw their community as the poorer for the population transfer. In this single village-setting, Tanc traces the impact of the various dimensions of the exchange elsewhere described at a broader level : the time-lag between the Orthodox exodus from Asia Minor and the arrival from Greece of the muhacirs, for example, which allowed contact, albeit fleeting, between the two refugee groups, but also created an interim period in which homes and gardens in Asia Minor, lying empty, were illegally occupied or looted.

19 As Tanc demonstrates, there are significant disagreements between these groups with regard to the interpretation of the past. This is particularly the case between the longterm residents and the muhacirs, who continue to distinguish themselves. Yet there are also surprising convergences, especially on the issue of good relations between the Orthodox and Muslim communities in the region, at least until the Balkan Wars. In the paper's conclusion, Tanc calls for further exploration of alternative histories of Asia Minor's past, to uncover such traces of pre- or anti-nationalist sentiments of intercommunal cooperation. 


\section{Conclusion : The Uses of Memory} emphasizing the lack of fit between representations and experiences of otherness, exploring the salience of movement between cities and villages or vice versa, or tracing the different effects of passing time for different refugee groups, the authors all seek to disrupt the easy slippage between "homeland" as imagined by individuals and families, and as defined and made sacred by national ideologies. Though memories may serve state agendas, and refugees in particular may find their pasts deployed to show national victimization, loss, and past greatness, close attention to the stories they tell permits us to see beyond histories that confuse attachment to locality with commitment to myths of national rootedness.

\section{NOTES}

1. The inspiration for this set of papers came from a group of presentations at a symposium hosted by the Center for the Study of South-Eastern Europe at the University of Wales in June 2000, entitled Intersecting Times: The Work of Memory in South-Eastern Europe. The papers by Georgios Tsimouris, Barbaros Tanc and Alice James were presented at the symposium, at which 
Peter Loizos served as commentator. Petar Krasztev and Nergis Canefe, both of whom had contributed different papers to the symposium, later volunteered papers on this theme for this collection, while the contributions from Miladina Monova and Samim Akgonul were added at the publication stage. I am grateful to my fellow symposium organizers Patrick Finney, Yannis Hamilakis, Margaret Kenna and Mark Pluciennek, to Yves Tomic and the Balkanologie editorial staff, and-especially-the authors-for their for their solidarity and patience. A grant to assist international attendance at the symposium was provided by the British Academy: we are also grateful to the University of Wales Collaboration Fund, which made the symposium and this publication possible. I would also like to thank Pamela Ballinger and Loring Danforth, who provided useful comments on sections of this introduction.

2. Herzfeld (Michael),Anthropology Through the Looking Glass : Critical Ethnography in the Margins of Europe, Cambridge : Cambridge University Press, 1987.

3. Fieldnotes in the Obrebski archive at the University of Massachussetts, Amherst. I am especially grateful to Professor Joel Halpern, and Mike Milewski, for alerting me to this material and facilitating my access.

4. Sistani (Lina), «Conceptualisations of "Turkish-ness" in a Macedonian community », Paper presented at Conference on Anthropology, Archaeology and Heritage in the Balkans and Anatolia, University of Wales, November 2001.

5. I have heard stories of this kind in Buf or Akritas in Greek Macedonia and on Samothraki in the Aegean. A succession of such past displacements led to the founding and growth of Krushevo, the Vlah town in the Republic of Macedonia.

6. Loizos (Peter), The Heart Grown Bitter : A Chronicle of Cypriot War Refugees, Cambridge : Cambridge University Press, 1981.

7. Herzfeld (Michael), «Foreword », in Hirschon (Renee), Heirs of the Greek Catastrophe: The Social Life of Asia Minor refugees in Piraeus, New York / Oxford : Berghahn, 1998.

8. Lavie (S.), Swedenburg (Ted), eds., Displacement, Diaspora and Geographies of Identity,Durham, NC : Duke University Press, 1996 ; Gupta (Akhil), Ferguson (James), eds., Culture, Power, Place : Explorations in Critical Anthropology, Durham / London: Duke University Press, 1997 ; Fog Olwig (Karen), Hastrup (Kirsten), eds., Siting Culture: The Shifting Anthropological Object, London: Routledge, 1997 ; Clifford (James), Routes:Travel and Translation in the Late Twentieth Century, Cambridge, MA : Harvard University Press, 1997.

9. Boyarin (Jonathan), ed., Space, Time and the Politics of Memory, Minneapolis: University of Minnesota Press, 1994 ; Bahloul (Joelle), The Architecture of Memory : A Jewish-Muslim Household in Colonial Algeria 1937--1962, Cambridge : Cambridge University Press, 1992 ; Parmentier (B.), Giving Voice to Stones: Place and Identity in Palestinian Literature, New York : Columbia University Press, 1994 ; Steen Preis (Ann-Belinda), « Seeking place : Capsized identities and Contracted Belonging among Sri Lankan Tamil Refugees », in Fog Olwig (Karen), Hastrup (Kirsten), eds., op. cit.

10. Malkki (Liisa), Purity and Exile: Violence, Memory and National Cosmology Among Hutu Refugees in Tanzania, Chicago : University of Chicago Press, 1995.

11. Bisharat (George E.), "Exile to Compatriot: Transformations in the Social Identity of Palestinian Refugees in the West Bank », in Gupta (Akhil), Ferguson (James), eds., op. cit.; Peteet (Julie), «Post Partition Palestinian Identities and the Moral Community », Social Analysis, 42 (1), 1998.

12. Peteet (Julie), loc. cit., p. 76.

13. Ibid.

14. Bisharat (George E.), loc. cit., p. 227.

15. Ibid., p. 224.

16. Ballinger (Pamela), Submerged Politics, Exiled Histories: Memory and Identity at the Borders of the Balkans, Princeton N.J. : Princeton University Press, forthcoming, chapter 7. 
17. David (Henry), « Involuntary International Migration », International Migration Review, 7 (3-4), 1969, cite in Malkki (Liisa), op. cit., p. 11.

18. Loizos (Peter), op. cit., pp. 144-145; Bisharat (George E.), loc. cit., p. 214 ; Ballinger (Pamela), op. cit. In Loizos' account, it is an exile from 1922 Smyrna who shows his key to a more recent internal Cypriot refugee, mocking the latter's hopes of return.

19. Hirschon (Renee), Heirs of the Greek Catastrophe: The Social Life of Asia Minor refugees in Piraeus, New York / Oxford: Berghahn, 1998, pp. 168-169 ; Loizos (Peter), op. cit., pp. 167-171; Bisharat (George E.), loc. cit., p. 213-215, 223.

20. Loizos (Peter), op. cit., pp. 157-163.

21. Ballinger (Pamela), op. cit.

22. The same question can be posed of the extensive resettlement of Greece's Asia Minor refugees in Macedonia, among Slavic-speaking minorities. where they significantly altered the demographic character of the territory.

INDEX

Mots-clés : Exil, Mémoire

\section{AUTEUR}

\section{KEITH S. BROWN}

Thomas J. Watson Institute for International Studies, Brown University, and University of Wales, Lampeter. 